\title{
Day-time variation of serum periostin in asthmatic adults treated with ICS/LABA and adults without asthma
}

\author{
Rachel Caswell-Smith ${ }^{1,2}$, Terrianne Cripps ${ }^{1}$, Thom Charles ${ }^{1}$, Alexander Hosking ${ }^{1,3}$, Meghana Handigol ${ }^{4}$, \\ Cecile Holweg ${ }^{4}$, John Matthews ${ }^{4}$, Mark Holliday' ${ }^{1}$, Corentin Maillot ${ }^{1}$, James Fingleton ${ }^{1}$, Mark Weatherall ${ }^{1,5}$, \\ Richard Beasley ${ }^{1,2,6^{*}}$, Irene Braithwaite ${ }^{1,2,6}$ and On behalf of the Periostin Study Team
}

\begin{abstract}
Background: We aimed to determine the effect of sampling time during the day on serum periostin levels in adult participants with and without asthma.

Methods: Serum periostin was measured at 2-h intervals from 0800 to $1800 \mathrm{~h}$ in 16 adult participants with stable asthma prescribed inhaled corticosteroid and long-acting beta-agonist therapy, and in 16 otherwise healthy participants without asthma. Mixed linear models were used to compare time zero (08:00 h) with subsequent measurement time for serum periostin for both groups.

Results: In both asthma and non-asthma, the mean (SD) serum periostin levels continuously reduced during the day from $53.5(13.6) \mathrm{ng} / \mathrm{mL}$ at $0800 \mathrm{~h}$ to $50.9(13.4) \mathrm{ng} / \mathrm{mL}$ at $1800 \mathrm{~h}$ (difference log periostin $-0.05, \mathrm{P} \leq 0.001$ ) and 50.5 (13.0) $\mathrm{ng} / \mathrm{mL}$ at $0800 \mathrm{~h}$ to $46.2(11.5) \mathrm{ng} / \mathrm{mL}$ at $1800 \mathrm{~h}$ (difference log periostin $-0.08, \mathrm{P} \leq 0.001$ ) respectively.

Conclusions: Periostin values are higher in the morning compared with the afternoon in asthmatic and non-asthmatic adults. The small magnitude of the variation in serum periostin levels suggests that the time of day in which the serum periostin measurements are made is unlikely to influence treatment decisions if a specific serum periostin level is used to predict treatment responsiveness.

Trial registration Australia New Zealand Trials Registry (ACTRN12614000072617)
\end{abstract}

Keywords: Asthma, Biomarker, Daytime variation, Periostin

\section{Background}

Asthma is a disease with an increasing global burden [1, 2]. Appropriate biomarkers may assist with determining clinical phentoypes, predicting treatment responsiveness, and directing personalized therapy [3, 4]. Currently recognized biomarkers include fraction of expired nitric oxide (FeNO), induced sputum and blood eosinophil levels, and total and specific IgE [3, 4]. Recently serum periostin, a matricellular protein generated by airway epithelial cells and partly regulated by IL-13, has been

\footnotetext{
*Correspondence: richard.beasley@mrinz.ac.nz

${ }^{1}$ Medical Research Institute of New Zealand, Private Bag 7902,

Wellington 6242, New Zealand

Full list of author information is available at the end of the article
}

proposed as a biomarker with a potential clinical role in severe asthma [5-8]. Serum periostin is a marker of type 2 inflammation, and has a stronger association with airways eosinophilia in severe asthma than blood eosinophil levels and FeNO [6]. High serum periostin levels may also predict responsiveness to monoclonal antibody therapy directed against IL-13 [9] IgE [10] and IL-4Ra [11]. This has led to the consideration of periostin as a predictive biomarker to identify patients most likely to respond to such monoclonal antibody therapies.

Recently we determined the reference ranges for serum periostin in two populations, an adult population without asthma or COPD [12], and an adult population with symptoms of airflow obstruction, predominantly adults with diagnosed asthma [13]. Clinical interpretation 
would be enhanced further by determining any timerelated variation in periostin measurements, particularly within the typical timeframe covered by clinic-based assessments in primary or specialist health practice. Time-related variations are reported for other type-2-related biomarkers in asthma such as sputum and blood eosinophils [14-18], and FeNO [19-21]. Measurements of these biomarkers are generally higher overnight and in the morning than in the afternoon.

We estimated the time-related variation in serum periostin levels in adults with asthma receiving maintenance ICS and long-acting beta agonist (LABA) therapy; the clinical population in which serum periostin levels are a predictor of responsiveness to monoclonal antibody therapy directed against IL-4, IL-13 and IgE [9-11]. We also estimated the time-related variation in serum periostin levels in adults without asthma, and compared the timerelated variations in serum periostin with those of other markers of type-2 dominant asthma, FeNO and blood eosinophils.

\section{Methods}

In this non-experimental cohort observational study we recruited adults aged 18-75 years of age, comprising 16 participants with asthma who were prescribed maintenance ICS and LABA therapy, (asthma group), and 16 participants who neither had a doctor diagnosis of asthma, symptoms of wheeze, or inhaler use in the past 12 months (non-asthma group). Exclusion criteria for both the asthma and non-asthma groups included: chronic bronchitis or COPD, known pregnancy, active (current, or within the three weeks prior to the visit) upper or lower respiratory tract infection, any of the following within the last 3 months; hospital admission, major surgery requiring general anesthetic, dental extractions or root canal procedures and bone fracture and any significant comorbidities or any safety concerns at the investigator's discretion.

\section{Study procedures}

Participants attended the clinical trials unit (CTU) at Capital and Coast District Health Board (CCDHB Wellington Hospital) for an initial visit (Visit 1) where the following procedures were completed: written informed consent, completion of a general health questionnaire [22], measurement of body mass index (BMI) and training in spirometry technique. Participants then attended the CTU on a second occasion (Visit 2) where blood samples were drawn every $2 \mathrm{~h}$ for serum periostin levels and peripheral blood eosinophil counts. Following each blood sample measures of FeNO, forced expiratory volume in $1 \mathrm{~s}\left(\mathrm{FEV}_{1}\right)$ and forced vital capacity $(\mathrm{FVC})$ were performed in accordance with ATS criteria [23, 24]. Six measurements were taken over the 10 -h period. Participants with asthma also completed the asthma control questionnaire-5 (ACQ-5) and the asthma quality of life questionnaire with standardized activities (AQLQ(S)) $[25,26]$.

\section{Medication use}

Participants with asthma were advised to take their regular ICS and LABA treatment in the morning prior to attending the clinic on Visit 2, and not to take any medication during the 10-h study period.

\section{Study power}

The clinically important difference in serum periostin is unknown. We chose a sample size of 16 , with $80 \%$ power, alpha $5 \%$, based on a paired $t$ test, to detect a paired difference of 0.75 standard deviations, for continuous variables, which constitutes in general terms a 'large' difference. This same sample size also has good precision for estimation of variance.

\section{Statistical methods}

Simple data descriptions are shown for the variables by asthma status. Serum periostin and FeNO were analyzed on the natural logarithm transformed scale. The exponent of a difference in logarithms can be interpreted as a ratio of geometric means. No transformations were done for other variables.

Mixed linear models were used to compare time zero with subsequent measurement time by asthma groups. The correlation structure for the repeated measures allowed for different correlations between the different measurements on the same participants, the 'unstructured' option in the statistical software. Simple unpaired $t$ tests were used to compare the baseline values for asthma versus non-asthma.

A post hoc analysis was undertaken to determine the proportion of adults with asthma that would change classification from 'high periostin' to 'low periostin', or from 'low periostin' to 'high periostin' based on the 0800 and $1800 \mathrm{~h}$ periostin levels, utilizing the proposed periostin cut point of $50 \mathrm{ng} / \mathrm{mL}$, used to determine responsiveness to monoclonal antibody therapies $[9,10]$.

SAS version 9.3 was used.

\section{Results}

\section{Participant characteristics}

The flow of participants in the study is shown in Fig. 1. Baseline characteristics for asthma and non-asthma participants are shown in Table 1 . All asthma participants were prescribed maintenance ICS/LABA inhaler therapy with a mean daily dose of $489 \mu \mathrm{g} /$ day of fluticasone propionate (FP) or equivalent as the ICS component. The 
Asthma Screened: $\mathrm{N}=29$

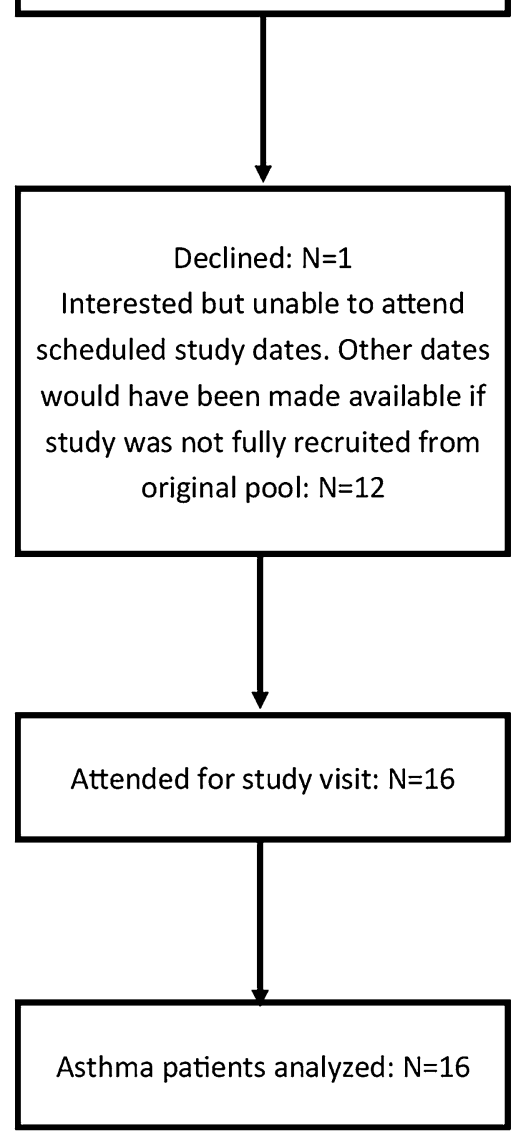

Fig. 1 Flow of participants through study
Non-asthma screened: $\mathrm{N}=\mathbf{2 8}$

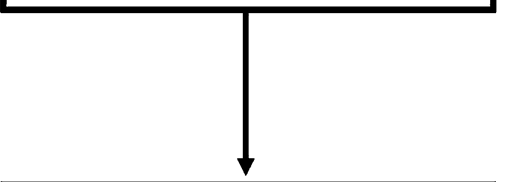

Excluded: Respiratory tract infec-

tion: $\mathrm{N}=1$

Interested but unable to attend scheduled study dates. Other dates would have been made available if study was not fully recruited from original pool: $\mathrm{N}=11$

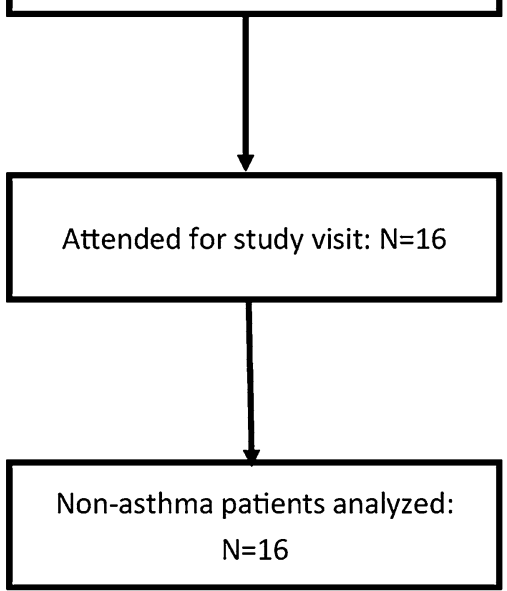

non-asthma participants were younger and had a lower BMI than the asthma participants. There were two current smokers, both of whom had asthma.

There was no statistically significant difference in periostin levels between the asthma and non-asthma groups at baseline (0800); difference $(95 \% \mathrm{CI})$ in logarithm periostin 0.058 ( -0.13 to 0.25$), \mathrm{P}=0.54$. This is equivalent to a mean ratio of serum periostin levels in the asthma versus non-asthma group of $1.06(0.88-1.28)$. There was no statistically significant difference in FeNO levels between the asthma and non-asthma groups at baseline (0800); difference $(95 \% \mathrm{CI})$ in logarithm FeNO $0.16(-0.25$ to 0.56$), \mathrm{P}=0.43$. This is equivalent to a mean ratio of FeNO levels in the asthma versus non-asthma group of 1.17 (0.78-1.76). There was weak evidence of a higher mean blood eosinophil count, $0.31 \times 10^{9} / \mathrm{L}$ in the asthma group, compared to $0.19 \times 10^{9} / \mathrm{L}$ in non-asthma, difference $(95 \% \mathrm{CI}), 0.11(-0.005$ to 0.23$), \mathrm{P}=0.06$.

\section{Day-time changes in asthma}

The serum periostin level decreased from a mean of $53.5 \mathrm{ng} / \mathrm{mL}$, at $0800 \mathrm{~h}$, to $50.9 \mathrm{ng} / \mathrm{mL}$ at $1800 \mathrm{~h}$. There 
Table 1 Baseline characteristics of participants

\begin{tabular}{|c|c|c|c|}
\hline Variable $\mathrm{N}=16$ & Mean (SD) & Median (IQR) & Min to $\max$ \\
\hline \multicolumn{4}{|l|}{ Asthma } \\
\hline Age (years) & $45.4(19.7)$ & 47 (25 to 63.5$)$ & $19-73$ \\
\hline $\operatorname{BMI}\left(\mathrm{kg} / \mathrm{m}^{2}\right)$ & $32.2(5.3)$ & $33.4(28.8-35.5)$ & $20.9-42.2$ \\
\hline $\mathrm{FEV}_{1} \%$ predicted $^{\mathrm{a}}$ & $90.5(18.1)$ & $96.6(81.9-102.9)$ & $50.6-111.6$ \\
\hline FEV1/FVC ratio ${ }^{b}$ & $0.82(0.04)$ & $0.81(0.79-0.85)$ & $0.77-0.89$ \\
\hline Mean ICS dose $e^{c}$ & $489(105.3)$ & $500(500-500)$ & $200-500$ \\
\hline Eosinophil count $\left(\times 10^{9} / L\right)^{d}$ & $0.31(0.20)$ & $0.25(0.20-0.35)$ & $0-0.7$ \\
\hline FeNO (ppb) & $26.1(13.3)$ & $23.5(16-36)$ & $7-55$ \\
\hline Periostin (ng/mL) & $53.5(13.6)$ & $51.7(41.5-63.7)$ & $33.9-76.2$ \\
\hline$A C Q-5^{e}$ & $1.3(1.2)$ & $1.2(0.4-1.4)$ & $0-4.0$ \\
\hline AQLQ(S) & $5.71(1.22)$ & $6.05(5.5-6.35)$ & $2.8-7.0$ \\
\hline Categorical variables & \multicolumn{2}{|c|}{ Number (\%) } & \\
\hline$A C Q \leq 0.75$ & \multicolumn{2}{|l|}{$5(31)$} & \\
\hline $\mathrm{ACQ} \geq 1.50$ & \multicolumn{2}{|l|}{$3(19)$} & \\
\hline ACQ $>0.75$ to $<1.50$ & \multicolumn{2}{|l|}{$8(50)$} & \\
\hline Atopy $^{f}$ (yes) & \multicolumn{2}{|l|}{$13(81)$} & \\
\hline Female & \multicolumn{2}{|l|}{$12(75)$} & \\
\hline Caucasian & \multicolumn{2}{|l|}{$12(75)$} & \\
\hline Asian & \multicolumn{2}{|l|}{$1(6)$} & \\
\hline Other & \multicolumn{2}{|l|}{$3(19)$} & \\
\hline Variable $\mathrm{N}=16$ & Mean (SD) & Median (IQR) & Min to $\max$ \\
\hline \multicolumn{4}{|l|}{ Non-asthma } \\
\hline Age (years) & $28.1(12.7)$ & $23(21-30.5)$ & $20-68$ \\
\hline $\mathrm{BMI}\left(\mathrm{kg} / \mathrm{m}^{2}\right)$ & $23.8(2.8)$ & $22.8(22.1-27.0)$ & $19.7-28.3$ \\
\hline $\mathrm{FEV}_{1} \%$ predicted $^{\mathrm{a}}$ & $97.9(10.5)$ & $96.3(90.8-105.7)$ & $80.5-120.9$ \\
\hline $\mathrm{FEV}_{1} / \mathrm{FVC}$ ratio $^{\mathrm{b}}$ & $0.85(0.03)$ & $0.86(0.85-0.88)$ & $0.77-0.88$ \\
\hline Eosinophil count $\left(\times 10^{9} / L\right)$ & $0.19(0.11)$ & $0.20(0.10-0.25)$ & $0.10-0.50$ \\
\hline FeNO (ppm) & $22.3(14.1)$ & $19.5(15.5-24.5)$ & $6.0-68.0$ \\
\hline Periostin (ng/mL) & $50.5(13.0)$ & $49.4(42.5-62.7)$ & $28.6-70.5$ \\
\hline Categorical variables & \multicolumn{2}{|c|}{ Number (\%) } & \\
\hline Atopy (yes) & \multicolumn{2}{|l|}{$5(31)$} & \\
\hline Female & \multicolumn{2}{|l|}{$11(69)$} & \\
\hline Caucasian & \multicolumn{2}{|l|}{$13(81)$} & \\
\hline Other & \multicolumn{2}{|l|}{$3(19)$} & \\
\hline
\end{tabular}

$S D$ standard deviation, IQR interquartile ratio, BMI body mass index, ICS inhaled corticosteroid, FeNO fraction of exhaled nitric oxide

${ }^{\text {a }} \mathrm{FEV}_{1}$ post-bronchodilator, expressed as $\%$ of normal predicted values

${ }^{b} \mathrm{FEV}_{1} / \mathrm{FVC}$ ratio, pre-bronchodilator

c ICS daily dose expressed as fluticasone propionate equivalent (microg/day)

${ }^{d}$ Eosinophil laboratory reference range: $0.0-0.5 \times 10^{9} / \mathrm{L}$, (measured in increments of 0.1 )

e ACQ-5: asthma control questionnaire-5, a score $>1.5$ indicates uncontrolled asthma [26]

${ }^{f}$ Atopy: a history of eczema and/or seasonal rhinitis

was strong evidence, overall $\mathrm{P}<0.001$, that the means by time were different, (Table 2; Fig. 2a; Additional file 1: Table S1, Figure S1). Compared with baseline, the log periostin was significantly lower from the 4-h $(1200 \mathrm{~h})$ to the $10-\mathrm{h}(1800 \mathrm{~h})$ time points, and the size of the difference remained constant from the 4-h time point. The ratio of geometric mean serum periostin compared to baseline was between 0.95 and 0.98 .

In a post hoc analysis of the asthma group, there was a change in classification from 'high periostin' to 'low periostin', based on the 0800 and $1800 \mathrm{~h}$ periostin levels, utilizing the proposed cut point of $50 \mathrm{ng} / \mathrm{mL}$ in $1 / 16$ 
Table 2 Serum periostin $(\mathrm{ng} / \mathrm{mL})$ levels at time points during study

\begin{tabular}{|c|c|c|c|c|c|c|}
\hline \multirow[t]{2}{*}{ Time points } & \multicolumn{6}{|l|}{ Periostin } \\
\hline & Mean (SD) & Median (IQR) & Min to $\max$ & $\begin{array}{l}\text { Difference from base- } \\
\text { line mean (SD) }\end{array}$ & $\begin{array}{l}\text { Difference }(95 \% \mathrm{Cl}) \\
\text { from baseline log periostin }^{\mathrm{a}}\end{array}$ & $\begin{array}{l}\text { Overall } P \\
\text { value }<0.001\end{array}$ \\
\hline \multicolumn{7}{|l|}{ Asthma } \\
\hline $0(0800)$ & $53.5(13.6)$ & $51.7(41.5-63.7)$ & $33.9-76.2$ & & & \\
\hline $2(1000)$ & $52.1(12.5)$ & $51.3(40.8-63.0)$ & $32-71.4$ & $-1.4(2.2)$ & $-0.02(-0.05$ to 0.003$)$ & 0.08 \\
\hline $4(1200)$ & $51.3(13.7)$ & $49.3(39.3-64.8)$ & $29.9-70.8$ & $-2.2(3.3)$ & $-0.05(-0.07$ to -0.02$)$ & $<0.001$ \\
\hline $6(1400)$ & $51.0(12.7)$ & $51.7(39.4-61.7)$ & $31.2-69.6$ & $-2.5(2.5)$ & $-0.05(-0.07$ to -0.02$)$ & $<0.001$ \\
\hline $8(1600)$ & $50.6(12.4)$ & $52.3(38.9-60.4)$ & $32.3-70.0$ & $-2.9(3.7)$ & $-0.05(-0.08$ to -0.03$)$ & $<0.001$ \\
\hline $10(1800)$ & $50.9(13.4)$ & $50.3(38.9-61.2)$ & $30.3-71.6$ & $-2.6(2.6)$ & $-0.05(-0.08$ to -0.03$)$ & $<0.001$ \\
\hline \multicolumn{7}{|l|}{ Non-asthma } \\
\hline $0(0800)$ & $50.5(13.0)$ & $49.4(42.5-62.7)$ & $28.6-70.5$ & & & \\
\hline $2(1000)$ & $50.3(13.4)$ & $48.6(39.7-61.2)$ & $28.7-72.7$ & $-0.2(2.7)$ & -0.006 ( -0.04 to 0.02$)$ & 0.71 \\
\hline $4(1200)$ & $47.7(12.2)$ & $46.3(39.5-59.7)$ & $27.7-67.0$ & $-2.8(2.5)$ & $-0.06(-0.09$ to -0.03$)$ & $<0.001$ \\
\hline $6(1400)$ & $46.6(11.3)$ & $45.0(39.8-53.8)$ & $28.6-65.5$ & $-3.9(3.6)$ & $-0.08(-0.11$ to -0.05$)$ & $<0.001$ \\
\hline $8(1600)$ & $46.5(11.9)$ & $43.8(38.6-55.9)$ & $27.9-68.2$ & $-4.0(2.9)$ & $-0.08(-0.11$ to -0.05$)$ & $<0.001$ \\
\hline $10(1800)$ & $46.2(11.5)$ & $46.6(37.7-55.0)$ & $29.2-66.3$ & $-4.2(3.2)$ & $-0.08(-0.11$ to -0.06$)$ & $<0.001$ \\
\hline
\end{tabular}

$S D$ standard deviation, IQR interquartile range, $C I$ confidence interval

a Difference from baseline is estimated from the mixed-effects linear model

participants $(50.3$ and $48.2 \mathrm{ng} / \mathrm{mL}$ at 0800 and $1800 \mathrm{~h}$, respectively) (Additional file 1: Table $\mathrm{S} 1$ ). There was no change in classification from 'low periostin' to 'high periostin', using the same criteria.

The FeNO decreased during the day from a peak mean of $26.1 \mathrm{ppb}$ at $0800 \mathrm{~h}$ to lowest level of $21.7 \mathrm{ppb}$ at $1800 \mathrm{~h}$. There was strong evidence, overall $\mathrm{P}<0.001$, that the means by time were different, (Table 3; Fig. 3a, Additional file 1: Table S2, Figure S2). Compared with baseline, the $\log$ FeNO was significantly lower from the 6-h (1400 h) to the $10-\mathrm{h}(1800 \mathrm{~h})$ time points. The size of the difference from the 6-h time point ranged from an estimate difference $(95 \% \mathrm{CI})$ of $-0.16(-0.26$ to -0.05$)$ to $-0.22(-0.33$ to -0.12$)$. The ratio of geometric mean FeNO compared to baseline was between 0.80 and 0.96 .

There was some evidence, $\mathrm{P}=0.02$, that the mean blood eosinophil count differed by time during the 10-h period of the study (Table 4) but none of the individual comparisons with baseline were statistically significant.

$\mathrm{FEV}_{1} \%$ predicted progressively decreased during the day from $90.5 \%$ at $0800 \mathrm{~h}$ to $85.8 \%$ at $1800 \mathrm{~h}$ (Additional file 1: Table S3). No participant received SABA for symptom relief during the 10 -h period of the study.

\section{Day-time changes in non-asthma}

Serum periostin level progressively decreased during the day from a mean of $50.5 \mathrm{ng} / \mathrm{mL}$ at $0800 \mathrm{~h}$ to $46.2 \mathrm{ng} /$ $\mathrm{mL}$ at $1800 \mathrm{~h}$. There was strong evidence, $\mathrm{P}<0.001$, that the means by time were different, (Table 2; Fig. 2b; Additional file 1: Table S4, Figure S3). The magnitude of the difference compared with baseline was, as for the asthma group, stable from the $4-\mathrm{h}(1200 \mathrm{~h})$ to the 10 -h $(1800 \mathrm{~h})$ time points. The ratio of geometric mean serum periostin compared to baseline was between 0.92 and 1.00 .

FeNO progressively decreased during the day from $22.3 \mathrm{ppb}$ at $0800 \mathrm{~h}$ to $18.5 \mathrm{ppb}$ at $1800 \mathrm{~h}$. There was strong evidence, $(\mathrm{P}=0.004)$, that the means by time were different, (Table 3; Fig. 3b; Additional file 1: Table S5, Figure S4). Compared with baseline, the log FeNO was significantly lower from the $10-\mathrm{h}(1800 \mathrm{~h})$ time point with an estimated difference $(95 \% \mathrm{CI})$ of $0.17(-0.28$ to -0.05 ; $\mathrm{P}=0.005)$. The ratio of geometric mean FeNO compared to baseline was between 0.84 and 0.98 .

Blood eosinophil count progressively decreased during the day from a mean of $0.19 \times 10^{9} / \mathrm{L}$ at $0800 \mathrm{~h}$ to a nadir of $0.13 \times 10^{9} / \mathrm{L}$. There was strong evidence that the means were different by time, $(\mathrm{P}<0.001)$ (Table 4$)$. Compared with baseline, the blood eosinophil count was significantly lower at the 2-, 4-, 6- and 8-h time points with estimated differences $(95 \% \mathrm{CI})$ ranging from -0.06 $(-0.09$ to -0.02$)$ to $-0.04(-0.08$ to -0.01$)$.

\section{Discussion}

This study shows that serum periostin levels vary throughout the day in adults with and without asthma, with higher levels in the morning in both groups. The magnitude of the variation was small, suggesting that the time that periostin levels are measured is unlikely to influence treatment decisions if predicting responsiveness to, or eligibility for monoclonal antibody therapy 

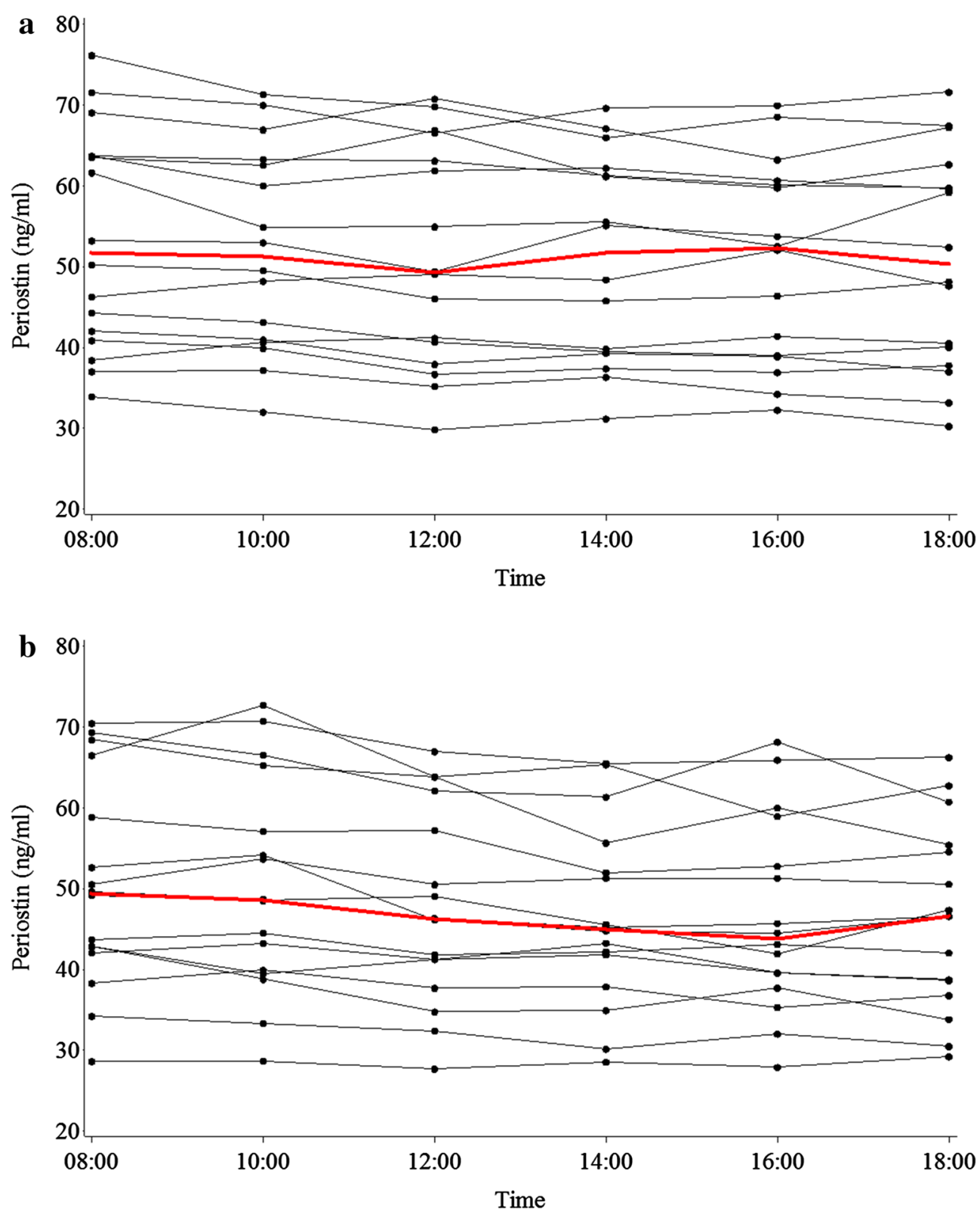

Fig. 2 Individual joined line plots for Periostin. Panel a shows the asthma group, Panel $\mathbf{b}$ shows the non-asthma group. The bold red line indicates the median periostin value

directed against IL-4Ra, IL-13, IgE or other components of type-2 inflammation in asthma.

The median baseline values of 51.7 and $49.4 \mathrm{ng} / \mathrm{mL}$ in the asthma and non-asthma groups respectively are similar to the median levels of $50.1 \mathrm{ng} / \mathrm{mL}$ in a population without asthma or COPD [12], $53.7 \mathrm{ng} / \mathrm{mL}$ in a random adult population with a diagnosis of asthma [13], and $50.2 \mathrm{ng} / \mathrm{mL}$ in adults with moderate to severe asthma inadequately controlled despite ICS therapy [9]. Interpretation of periostin levels might be confounded by the observation that initiation of ICS therapy may result in a modest reduction in serum periostin by a mean of $5.3 \mathrm{ng} /$ $\mathrm{mL}$ [13]. Together, these findings suggest that serum periostin is not a measure which can differentiate patients with asthma across a range of severity from a population without asthma.

The daytime variation we have found with serum periostin levels is similar to that reported previously for the type 2-related biomarkers of sputum and blood eosinophils [14-18] and FeNO [19-21]. In allergic subjects 
Table 3 FeNO (ppb) levels at time points during study

\begin{tabular}{|c|c|c|c|c|c|c|}
\hline \multirow[t]{2}{*}{ Time points } & \multicolumn{6}{|l|}{ FeNO } \\
\hline & Mean (SD) & Median (IQR) & Min to $\max$ & $\begin{array}{l}\text { Difference from } \\
\text { baseline mean (SD) }\end{array}$ & $\begin{array}{l}\text { Difference }(95 \% \mathrm{Cl}) \\
\text { from baseline log } \mathrm{FeNO}^{\mathrm{a}}\end{array}$ & $\begin{array}{l}\text { Overall } \\
P \text { value }<0.001\end{array}$ \\
\hline \multicolumn{7}{|l|}{ Asthma } \\
\hline $0(0800)$ & $26.1(13.3)$ & $23.5(16-36)$ & $7.0-55.0$ & & - & - \\
\hline $2(1000)$ & $25.1(13.3)$ & $24.0(15-34)$ & $7.0-54.0$ & $-1.0(5.2)$ & $-0.04(-0.15$ to 0.07$)$ & 0.44 \\
\hline $4(1200)$ & $25.8(16.7)$ & $22.0(13.5-31.5)$ & $7.0-63.0$ & $-0.3(8.8)$ & $-0.05(-0.16$ to 0.05$)$ & 0.32 \\
\hline $6(1400)$ & $22.8(12.4)$ & $21.0(13-31)$ & $5.0-51.0$ & $-3.3(6.1)$ & $-0.16(-0.26$ to -0.05$)$ & 0.005 \\
\hline $8(1600)$ & $21.3(12.9)$ & $19.0(13.5-24.5)$ & $7.0-58.0$ & $-4.9(5.7)$ & $-0.22(-0.33$ to -0.12$)$ & $<0.001$ \\
\hline $10(1800)$ & $21.7(12.1)$ & $19.5(12.5-29)$ & $8.0-54.0$ & $-4.4(4.5)$ & $-0.18(-0.29$ to -0.07$)$ & 0.001 \\
\hline \multicolumn{7}{|l|}{ Non-asthma } \\
\hline $0(0800)$ & $22.3(14.1)$ & $19.5(15.5-24.5)$ & $6.0-68.0$ & & - & - \\
\hline $2(1000)$ & $23.6(14.9)$ & $19.5(16.5-27.5)$ & $6.0-73.0$ & $1.4(2.2)$ & $0.06(-0.05$ to 0.18$)$ & 0.30 \\
\hline $4(1200)$ & $21.3(13.9)$ & $17.0(13.5-27.0)$ & $7.0-66.0$ & $-1.1(3.0)$ & $-0.05(-0.17$ to 0.06$)$ & 0.38 \\
\hline $6(1400)$ & $22.8(18.6)$ & $16.0(15.0-26.0)$ & $7.0-88.0$ & $0.4(6.6)$ & $-0.02(-0.14$ to 0.09$)$ & 0.72 \\
\hline $8(1600)$ & $20.9(15.4)$ & $17.0(13.0-23.5)$ & $6.0-72.0$ & $-1.4(5.9)$ & $-0.10(-0.22$ to 0.01$)$ & 0.09 \\
\hline $10(1800)$ & $18.5(11.2)$ & $16.0(13.0-21.5)$ & $6.0-56.0$ & $-3.8(5.5)$ & $-0.17(-0.28$ to -0.05$)$ & 0.005 \\
\hline
\end{tabular}

$S D$ standard deviation, IQR interquartile range, $\mathrm{Cl}$ confidence interval, FeNO fraction of exhaled nitric oxide

a Difference from baseline is estimated from the mixed-effects linear model

with mild asthma, sputum eosinophils are about twofold higher at $0700 \mathrm{~h}$ than at $1600 \mathrm{~h}$ [14]. Additionally, the early morning increase in sputum eosinophils correlated with enhanced airway obstruction and reversibility, suggesting that airway recruitment of eosinophils might contribute to circadian variations in lung function in patients with asthma [14].

In adults with mild asthma, blood eosinophil counts are about $25 \%$ higher at $0400 \mathrm{~h}$ than at $1600 \mathrm{~h} \mathrm{[15].} \mathrm{It}$ has been observed that the circadian change in blood eosinophils and lung function appear to fall into a continuous range, suggesting that day/night variations in airways inflammation and lung function occur as a continuum, rather than as an all or nothing phenomenon [15]. In allergic subjects with moderately severe asthma, a circadian variation in blood eosinophil counts was also observed with peak values overnight [16]. In healthy subjects, blood eosinophil counts may also vary diurnally, being lowest in the morning and highest at night, correlating inversely to blood cortisol levels [17]. The demonstration of daytime variation in the non-asthma, but not the asthma group in our study is likely to reflect the lack of power, low sensitivity of the automated measurement of blood eosinophil levels to increments of 0.1 per $10^{9} / \mathrm{L}$, and possibly the effect of the maintenance treatment with ICS in all asthma participants.

In asthma, there is a variable degree of diurnal variation in FeNO, which is greatest in uncontrolled disease and serves as a predictor of risk of future exacerbations [19-21]. The mean diurnal FeNO variation, measured as the difference in morning $(0700-1000 \mathrm{~h})$ from evening (1800-2100 h) levels over a two-week period, was $15.6 \mathrm{ppb}$ in uncontrolled asthma subjects compared with $8.2 \mathrm{ppb}$ in stable controlled asthma, and $6.1 \mathrm{ppb}$ in healthy subjects [21]. In another study of adults with asthma, morning FeNO levels were reported to be $14 \%$ higher than evening levels [19]. In our study we observed a mean difference in FeNO between 0800 and $1800 \mathrm{~h}$ on a single day of $4.4 \mathrm{ppb}$ in controlled asthma and $3.8 \mathrm{ppb}$ in non-asthma. Finally, the lesser variability, based on the ratio of geometric mean values compared to baseline, of serum periostin levels compared with FeNO levels in our study is consistent with previous observations that there is a lesser intra-patient variability in periostin levels compared with FeNO [9].

The clinical relevance of our findings is illustrated by the post hoc analysis in which we determined that only one in 16 asthma participants changed their periostin classification between 'high periostin' and 'low periostin', based on the 0800 and $1800 \mathrm{~h}$ levels, utilizing the proposed periostin cut point of $50 \mathrm{ng} / \mathrm{mL}$, used to determine responsiveness to monoclonal antibody therapy directed against IL-13 [9], and IgE [10]. Thus daytime variation of periostin is unlikely to be an important consideration using the $50 \mathrm{ng} / \mathrm{mL}$ cut point. However, the validity of the cut-point as a predictor of responsiveness will need to be confirmed in future studies utilizing the same assay and a cut-off needs to be established if other assays are used. Although the used assay has a very good precision around the cut-point of $50 \mathrm{ng} / \mathrm{mL}$ (repeatability 

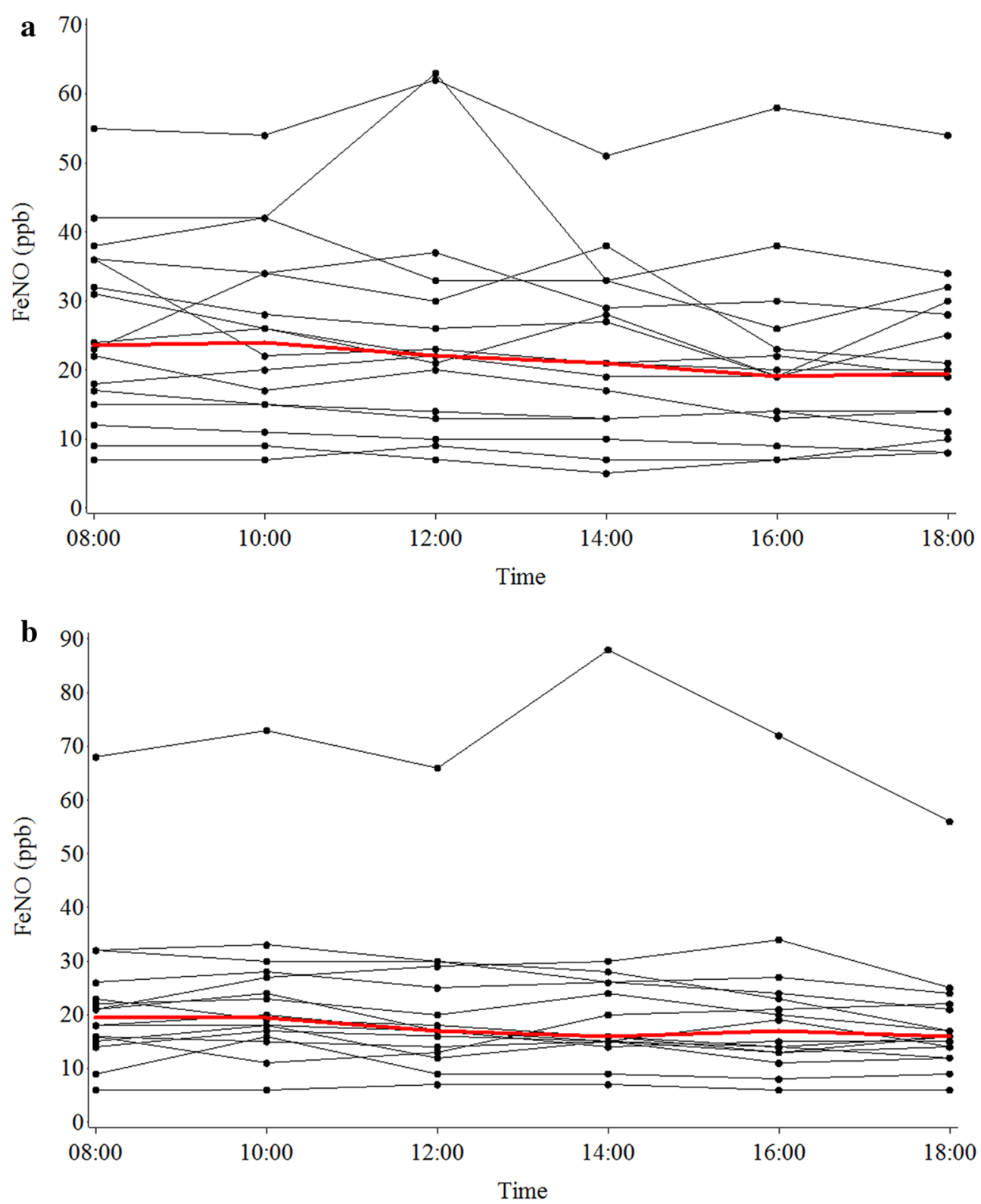

Fig. 3 Individual joined line plots for the fraction of exhaled nitric oxide (FeNO). Panel a shows the asthma group and Pane/ b shows the nonasthma group. The bold red line indicates the median FeNO value

CV $0.9-1.5 \%$, intermediate precision CV $1.2-1.7 \%$ and reproducibility CV $1.7-3.1 \%$ ), a degree of error of misclassification cannot be excluded It should also be noted that the assay used has a reproducibility $\mathrm{CV}$ of $1.7-3.1 \%$ around the $50 \mathrm{ng} / \mathrm{mL}$ cut point of $1.7-3.1 \%$, introducing a degree of reproducibility error when taking repeat samples [27].

There are a number of methodological limitations relevant to the interpretation of the study findings. No adjustment has been made for multiple statistical testing, thus the findings should be considered illustrative. The findings are generalizable to Caucasian adults with asthma on regular ICS and LABA treatment, representing GINA Step 3 and 4 therapy [28], but generalizability to other ethnicities is less certain. ICS reduces serum periostin levels [13], FeNO [29-31], and blood eosinophil counts [16], however the effect of ICS on the circadian rhythm of periostin is not known. Periostin levels are unlikely to have been influenced by the presence or absence of atopy in either the asthma or 
Table 4 Blood eosinophil ( $\times 10^{9} / \mathrm{L}$ ) levels at time points during study

\begin{tabular}{|c|c|c|c|c|c|}
\hline \multirow[t]{2}{*}{ Time points } & \multicolumn{5}{|c|}{ Blood eosinophil } \\
\hline & Mean (SD) & Median (IQR) & Min to $\max$ & $\begin{array}{l}\text { Difference }(95 \% \mathrm{CI}) \\
\text { from baseline }^{\mathrm{a}}\end{array}$ & $\begin{array}{l}\text { Overall } \\
P \text { value }=0.015\end{array}$ \\
\hline \multicolumn{6}{|l|}{ Asthma } \\
\hline $0(0800)$ & $0.31(0.20)$ & $0.25(0.20-0.35)$ & $0-0.7$ & - & - \\
\hline $2(1000)$ & $0.31(0.20)$ & $0.20(0.20-0.40)$ & $0.10-0.7$ & 0.006 (-0.03 to 0.04$)$ & 0.71 \\
\hline $4(1200)$ & $0.29(0.20)$ & $0.20(0.15-0.40)$ & $0.10-0.7$ & $-0.02(-0.05$ to 0.01$)$ & 0.26 \\
\hline $6(1400)$ & $0.29(0.21)$ & $0.2(0.1-0.4)$ & $0.1-0.8$ & $-0.02(-0.05$ to 0.01$)$ & 0.26 \\
\hline $8(1600)$ & $0.31(0.19)$ & $0.25(0.20-0.40)$ & $0.1-0.7$ & $0(-0.03$ to 0.03$)$ & 0.99 \\
\hline $10(1800) N=15$ & $0.34(0.21)$ & $0.30(0.20-0.40)$ & $0.1-0.8$ & $0.02(-0.01$ to 0.06$)$ & 0.20 \\
\hline \multicolumn{6}{|l|}{ Non-asthma } \\
\hline $0(0800)$ & $0.19(0.11)$ & $0.20(0.10-0.25)$ & $0.10-0.50$ & - & - \\
\hline $2(1000)$ & $0.16(0.10)$ & $0.10(0.10-0.20)$ & $0.20-0.50$ & $-0.04(-0.07$ to -0.01$)$ & 0.023 \\
\hline $4(1200) N=15$ & $0.13(0.10)$ & $0.10(0.10-0.20)$ & $0-0.4$ & $-0.06(-0.09$ to -0.02$)$ & 0.001 \\
\hline $6(1400)$ & $0.14(0.10)$ & $0.10(0.10-0.20)$ & $0.0-0.3$ & $-0.06(-0.09$ to -0.02$)$ & $<0.001$ \\
\hline $8(1600)$ & $0.15(0.08)$ & $0.10(0.10-0.20)$ & $0.10-0.30$ & $-0.04(-0.08$ to -0.01$)$ & 0.008 \\
\hline $10(1800) N=15$ & $0.17(0.09)$ & $0.10(0.10-0.20)$ & $0.10-0.40$ & $-0.03(-0.06$ to 0.01$)$ & 0.13 \\
\hline
\end{tabular}

$S D$ standard deviation, IQR interquartile range, $\mathrm{Cl}$ confidence interval

a Difference from baseline is estimated from the mixed-effects linear model

non-asthma group $[12,13]$, but It is possible that serum periostin levels may show a greater magnitude of circadian variability in a population in which there is a greater proportion with uncontrolled disease, similar to an effect shown with FeNO [21]. In this sample there were no participants on chronic oral corticosteroids however this is a group that might be more likely to be considered for monoclonal antibody therapy regardless of serum periostin levels. The use of LABA therapy prior to the baseline morning measurements and no subsequent medication use during the period of the study, is unlikely to have influenced the periostin or FeNO levels, but may have resulted in the gradual reduction in $\mathrm{FEV}_{1}$ during the study period as the bronchodilator effect of the LABA wore off.

\section{Conclusions}

We conclude that there is day-time variation of serum periostin in adults with asthma receiving maintenance ICS and LABA therapy, with higher levels in the morning. The magnitude of the variation in serum periostin levels is of uncertain clinical significance, however, the time of day at which the blood sample is drawn was unlikely to influence treatment decisions if a specific serum periostin level was used to predict treatment responsiveness in the asthma group.

\section{Additional file}

Additional file 1. Additional figures and tables.

\section{Abbreviations}

COPD: chronic obstructive pulmonary disease; $\mathrm{FEV}_{1}$ : forced expiratory volume in $1 \mathrm{~s}$; FeNO: fraction of exhaled nitric oxide; GERD: gastro-esophageal reflux disease; ICS: inhaled corticosteroids; IQR: interquartile range; IL: interleukin; IgE: immunoglobulin E; LABA: long-acting beta-agonist; SABA: short-acting betaagonist; YKL-40: human cartilage glycoprotein -39.

\section{Authors' contributions}

Conception and design: RB, IB. RCS, JF, CH, MH, JM, MW, data collection: RCS, TC, TC, AH; analysis and data interpretation: RB, RCS, CH, JM, MW. The first draft was written by RCS. All authors contributed to the revision of the paper. All authors read and approved the final manuscript.

\section{Author details}

${ }^{1}$ Medical Research Institute of New Zealand, Private Bag 7902, Wellington 6242, New Zealand. ${ }^{2}$ Victoria University of Wellington, Wellington, New Zealand. ${ }^{3}$ University of Auckland, Auckland, New Zealand. ${ }^{4}$ Genentech Inc, San Francisco, CA, USA. ${ }^{5}$ University of Otago, Wellington, New Zealand. ${ }^{6}$ Capital \& Coast District Health Board, Wellington, New Zealand.

\section{Acknowledgements}

We are grateful to the study participants for their involvement in the study. The Periostin Study Group Rachel Caswell-Smith, James Fingleton, Richard Beasley, Irene Braithwaite, Tony Mallon, Judith Riley, Janine Pilcher, Mark Weatherall, Mathew Williams, Philippa Shirtcliffe, Thomas Charles, Mark Holliday, Maureen Stretch, Alison Pritchard, Denise Fabian, Alexander Hosking (Medical Research Institute of New Zealand). Meghana Handigol, Cecile Holweg, John Matthews (Genentech Inc). 


\section{Competing interests}

The primary funder of this study was Genentech Inc, USA. Dr. Holweg, Dr. Matthews and Ms. Handigol are members of the Periostin Study Group, and employees of Genentch Inc, USA. There are no other competing interests to declare.

\section{Availability of data and materials}

The datasets used and/or analysed during this study are available from the corresponding author on reasonable request.

\section{Ethics approval and consent to participate}

Ethical approval was given by the Central Regional Ethics Committee of New Zealand (13/NTB/184/AM02). Written informed consent was obtained from all participants prior to study procedures being undertaken.

\section{Funding}

This study was funded by Genentech Inc, USA. The above named employees of Genentech were involved in the study design and data interpretation. They were not involved in the data collection or the statistical analysis of the study.

Received: 9 December 2016 Accepted: 26 January 2017

Published online: 08 February 2017

\section{References}

1. Masoli M, Fabian D, Holt S, Beasley R. Global burden of asthma. Global initiative for asthma (GINA) 2004. http://www.ginasthma.com. Accessed Dec 52016.

2. Eder W, Ege MJ, von Mutius E. The asthma epidemic. N Engl J Med. 2006;355:2226-35.

3. Taylor DR. Using biomarkers in the assessment of airways disease. J Allergy Clin Immunol. 2011;128:927-34.

4. Szefler SJ, Wenzel S, Brown R, Erzurum SC, Fahy JV, Hamilton RG, Hunt JF, Kita H, Liu AH, Panettieri RA Jr, Schleimer RP, Minnicozzi M. Asthma outcomes: biomarkers. J Allergy Clin Immunol. 2012;129(Suppl 3):S9-23.

5. Woodruff PG, Modrek B, Choy DF, Jia G, Abbas AR, Ellwanger A, Koth LL, Arron JR, Fahy JV. T-helper type 2-driven inflammation defines major subphenotypes of asthma. Am J Respir Crit Care Med. 2009;180:388-95.

6. Jia G, Erickson RW, Choy DF, Mosesova S, Wu LC, Solberg OD, Shikotra A, Carter R, Audusseau S, Hamid Q, Bradding P, Fahy JV, Woodruff PG, Harris JM, Arron JR. Bronchoscopic exploratory research study of biomarkers in corticosteroid-refractory asthma (BOBCAT) study group. Periostin is a systemic biomarker of eosinophilic airway inflammation in asthmatic patients. J Allergy Clin Immunol. 2012;130:647-54.

7. Takayama G, Arima K, Kanaji T, Toda S, Tanaka H, Shoji S, McKenzie AN, Nagai H, Hotokebuchi T, Izuhara K. Periostin: a novel component of subepithelial fibrosis of bronchial asthma downstream of IL-4 and IL-13 signals. J Allergy Clin Immunol. 2006;118:98-104.

8. Woodruff PG, Boushey HA, Dolganov GM, Barker CS, Yang YH, Donnelly S, Ellwanger A, Sidhu SS, Dao-Pick TP, Pantoja C, Erle DJ, Yamamoto KR, Fahy JV. Genome-wide profiling identifies epithelial cell genes associated with asthma and with treatment response to corticosteroids. Proc Natl Acad Sci USA. 2007;104:15858-63.

9. Corren J, Lemanske RF, Hanania NA, Korenblat PE, Parsey MV, Arron JR, Harris JM, Scheerens H, Wu LC, Su Z, Mosesova S, Eisner MD, Bohen SP Matthews JG. Lebrikizumab treatment in adults with asthma. N Engl J Med. 2011;365:1088-98.

10. Hanania NA, Wenzel S, Rosen K, Hsieh HJ, Mosesova S, Choy DF, Lal P, Arron JR, Harris JM, Busse W. Exploring the effects of omalizumab in allergic asthma: an analysis of biomarkers in the EXTRA study. Am J Respir Crit Care Med. 2013;187:804-11.

11. Wenzel S, Swanson B, Teper A, Hamilton J, Izuhara K, Ohta S, et al. Dupilumab reduces severe exacerbations in periostin-high and periostinlow asthma patients. Eur Respir J. 2016;48(Suppl 60):1798.

12. Caswell-Smith R, Hosking A, Cripps T, Holweg C, Matthews J, Holliday M, Maillot C, Fingleton J, Weatherall M, Beasley R. Reference ranges for serum periostin in a population without asthma or COPD. Clin Exp Allergy. 2016. doi:10.1111/cea.12763.
13. Fingleton J, Braithwaite I, Travers J, Bowles D, Strik R, Siebers R, Holweg C, Matthews J, Weatherall M, Beasley R, NZRHS Study Group. Serum periostin in obstructive airways disease: distribution, relationships, and steroid responsiveness. Eur Resp J. 2016. doi:10.1183/13993003.01384-2015.

14. Panzer SE, Dodge AM, Kelly EA, Jarjour NN. Circadian variation of sputum inflammatory cells in mild asthma. J Allergy Clin Immunol. 2003:111:308-12.

15. Kelly EA, Houtman JJ, Jarjour NN. Inflammatory changes associated with circadian variation in pulmonary function in subjects with mild asthma. Clin Exp Allergy. 2004;34:227-33.

16. Wempe JB, Tammeling EP, Koeter GH, Hakansson L, Venge P, Postma DS. Blood eosinophil numbers and activity during $24 \mathrm{~h}$ : effects of treatment with budesonide and bambuterol. J Allergy Clin Immunol. 1992;90:757-65.

17. Winkel P, Statland BE, Saunders AM, Osborn H, Kupperman H. Within-day physiologic variation of leukocyte types in healthy subjects as assayed by two automated leukocyte differential analyzers. Am J Clin Pathol. 1981;75:693-700

18. Uhrbrand $\mathrm{H}$. The number of circulating eosinophils; normal figures and spontaneous variations. Acta Med Scand. 1958;160:99-104.

19. Pijnenburg MW, Floor SE, Hop WC, De Jongste JC. Daily ambulatory exhaled nitric oxide measurements in asthma. Pediatr Allergy Immunol. 2006;17:189-93.

20. ten Hacken $\mathrm{NH}$, van der Vaart $\mathrm{H}$, van der MarkTW, Koeter GH, Postma DS. Exhaled nitric oxide is higher both at day and night in subjects with nocturnal asthma. Am J Respir Crit Care Med. 1998;158:902-7.

21. Saito J, Gibeon D, Macedo P, Menzies-Gow A, Bhavsar PK, Chung KF. Domiciliary diurnal variation of exhaled nitric oxide fraction for asthma control. Eur Respir J. 2014:43:474-84.

22. Juniper EF, Guyatt GH, Epstein RS, Ferrie PJ, Jaeschke R, Hiller TK. Evaluation of impairment of health-related quality of life in asthma: development of a questionnaire for use in clinical trials. Thorax. 1992;47:76-83.

23. Offline NO. ATS/ERS Recommendations for standardized procedures for the online and offline measurement of exhaled lower respiratory nitric oxide and nasal nitric oxide. Am J Respir Crit Care Med. 2005;171:912-30.

24. Miller MR, Hankinson J, Brusasco V, Burgos F, Casaburi R, Coates A, Crapo R, Enright P, van der Grinten CP, Gustafsson P, Jensen R, Johnson DC, Maclntyre N, McKay R, Navajas D, Pedersen OF, Pellegrino R, Viegi G, Wanger J, ATS/ERS Task Force. Standardisation of spirometry. Eur Respir J. 2005:26:319-38.

25. Juniper EF, Svensson K, Mork AC, Stahl E. Measurement properties and interpretation of three shortened versions of the asthma control questionnaire. Respir Med. 2005;99:553-8.

26. Juniper EF, Bousquet J, Abetz L, Bateman ED. The GOAL committee identifying 'well controlled' and 'not well controlled' asthma using the Asthma Control Questionnaire. Respir Med. 2006;100:616-21.

27. Palme S, Christenson RH, Jortani SA, Ostlund RE, Kolm R, Kopal G, Laubender RP. Multicenter evaluation of analytical characteristics of the Elecsys ${ }^{\circledR}$ periostin immunoassay. Clin Biochem. 2016.

28. Global initiative for asthma. Global strategy for asthma management and prevention; 2015.http://www.ginasthma.org. Accessed 13th July 2015.

29. Jones SL, Herbison P, Cowan JO, Flannery EM, Hancox RJ, McLachlan CR, Taylor DR. Exhaled NO and assessment of anti-inflammatory effects of inhaled steroid: dose-response relationship. Eur Respir J. 2002;20:601-8.

30. Lim KG, Mottram C. The use of fraction of exhaled nitric oxide in pulmonary practice. Chest. 2008;133:1232-42.

31. Shaw DE, Wilson E, Pavord ID. Exhaled nitric oxide in asthma. In: European respiratory monograph: ERS 2010;49 Chapter 2:32-44. 